\title{
Infectious Cystitis
}

National Cancer Institute

\section{Source}

National Cancer Institute. Infectious Cystitis. NCI Thesaurus. Code C83816.

An infectious process affecting the urinary bladder. 